\title{
PLANNING PROCEDURES TOWARDS HIGH CLIMATIC QUALITY CITIES. EXAMPLE REFERRING TO LISBON
}

\author{
MARIA JoÃo AlCOFORADO ${ }^{1}$
}

\begin{abstract}
The different stages of research on high climatic quality city are presented in this paper: acquisition of appropriate urban climate information, analysis of different urban climate features and selection of planning strategies (accordingly with the climate zone). Then, with the aid of a GIS, systematic guidelines for planning can be given. As a result, different types of benefits for city dwellers are to be expected (comfort, health, economic). Lisbon is presented as a case study. It is shown how the "translation" of the knowledge of Lisbon's urban climate into simple guidelines for urban planning in order to mitigate the urban heat island, promote ventilation and increase air quality, was carried out. To this end, maps of the physical features of the city of Lisbon were drawn, synthesised into "urban homogeneous units" maps. Climate guidelines are specified for six groups of units (brought together according to urban morphology, topography and position in town).
\end{abstract}

Key words: Urban planning, climate guidelines, urban climate, Lisbon, Portugal.

Resumo - MEdidAs DE ORDENAMENTO PARA MELHORAR A QUALIDADE DO CLIMA URBANO. EXEMPLO REFERENTE A LISBOA. As diferentes fases da investigação para uma melhor qualidade do clima urbano são enunciadas: aquisição de dados segundo regras precisas, análise das características do clima urbano e selecção de estratégias para o ordenamento (em função da zona climática). A partir deste estádio, é possível enunciar orientações para o planeamento. O caso de Lisboa é apresentado como exemplo. É proposta uma metodologia para "traduzir" os conhecimentos sobre o clima urbano de Lisboa numa série de orientações para o ordenamento, com o intuito de mitigar a ilha de calor, promover a ventilação e aumentar a qualidade do ar. Neste sentido, foram elaborados mapas das características físicas da cidade de Lisboa, depois sintetizados no mapa das "unidades urbanas homogéneas" (agrupadas em função da morfologia urbana, topografia e posição na cidade): para cada uma destas unidades foram enunciadas orientações para o planeamento.

Palavras-chave: Ordenamento urbano, orientações climáticas, clima urbano, Lisboa, Portugal.

1 Investigadora do Centro de Estudos Geográficos da Universidade de Lisboa e Professora Catedrática do Departamento de Geografia. E-mail: mjalc@fl.ul.pt 
Résumé - Mesures Pour améliorer la QuAlité du Climat uRBain. ExemPle DE LisBOnNE. Les différentes étapes de la recherche pour contribuer à la qualité du climat en ville sont présentées : acquisition de données climatiques urbaines suivant des règles précises, analyse des caractéristiques du climat urbain et sélection de stratégies pour l'aménagement (en fonction de la zone climatique). Finalement des recommendations pour l'aménagement peuvent être présentées (sous forme de documents cartographiques, avec utilisation de Systèmes d'Information Géographique ou de textes). Le cas de Lisbonne est cité comme exemple. On propose une méthodologie pour "traduire" les connaissances sur le climat urbain de Lisbonne en une série de recommendations pour l'aménagement, avec l'objectif de mitiger l'îlot de chaleur urbain, promouvoir la ventilation et augmenter la qualité de l'air. Plusieurs cartes des caractéristiques physiques de la ville ont été préparées, qui ont conduit à une carte de synthèse des "unités urbaines homogènes" (des points de vue de la morphologie urbaine, topographie et position en ville); des mesures ont été enoncées pour chacune de ces unités.

Mots-clés: Aménagement urbain, recommendations pour l'aménagement, climat urbain, Lisbonne, Portugal.

\section{INTRODUCTION}

Climate can be seen as a resource for different objectives such as freshwater availability, food security, renewable energies, human health, integrated planning and tourism. This paper deals with integrated planning issues. Mills (2006) clearly stated, "as the global population becomes urbanized and human activity is concentrated in urban areas, settlement planning is the key aspect of sustainability". However, "economic and social demands are frequently in conflict with environmental issues" (Fehrenbach et al., 2001). Among the latter, there are laws limiting noise, air and water pollution and favouring biodiversity, but until now "local climate still is of minor importance for urban and regional planning" (Fehrenbach et al., 2001). The aim of this paper is to show that the systematic inclusion of urban climate knowledge into the planning processes is crucial for a better quality of life in cities. Last but not least, as man grows more aware about the problems of global warming and temperature rise in cities, it seems wise to follow the advice "think global, act local".

\section{THE METEOROLOGICAL UTOPIAN CITY: FROM LANSBERG TO MILLS}

Climate is an aspect of the urban physical urban environment that can be improved, although the metutopia, defined by Landsberg over 30 years ago, may never be attained. As early as 1973 Landsberg warned that "there are some sound meteorological principles that must begin to penetrate the planning process". Several very simple rules are listed such as not using flood 
plains for urban areas; unfortunately there are many examples that show that this advice should have been taken. In order to avoid summer urban heat island (see III.2.) in the utopian city, surfaces covered by vegetation should be as large as possible (if possible natural trees and shrubs, as grass often dries out in summer) and parking lots should be replaced by underground parking. Buildings should be high so as to occupy less space and anthropogenic heat should in winter be "channelled through smoke sewers (...) to melt snow that cause accidents and traffic jams". He describes other measures to avoid wind channelling by streets, air pollution and noise, pointing out consequences that bad environment would have on city dwellers. Other measures are put forward, not all of them accepted by everyone such as the use of atomic energy. It is quite interesting to note that Landsberg was already writing about "air resource" (p. 88). From his standpoint this resource had been "overexploited if not depleted". He was probably thinking about air pollution that was (and still is) destroying "otherwise pleasant climatic settings". Landsberg's approach has been brought back by some other authors. Bitan (1992: 313) was one of the first authors who distinguished urban air quality (air pollution, that must be controlled) from climate quality: "by correct usage of different climatological elements and their correct integration in different levels of planning (...), one can lead up to the improvement of local climates". He gives an example of a city with no air pollution problems, but with poor climate quality for the urban population (taking into account ventilation, sun rights or shade areas, excessively high temperatures, etc.). A decade later, Mills (2003: 227) presented a paper at the International Conference on Urban Climate (ICUC5) in Lödz, on "The meteorologically utopian city revisited", in which he states that "the new urban utopia is the sustainable city". He highlights the "consequences of design decisions carried out to solve different problems at varying scales". From his paper and a subsequent one (Mills, 2006), the reader will see that the planning objectives must be analysed at three different scales (settlement, building groups and individual buildings); furthermore, in some cases conflicts arise between the solutions carried out at the three different scales, and the planner must be aware of this.

\section{PROCEDURES TO ACHIEVE A HIGH CLIMATIC QUALITY CITY}

\section{The use of climatic information (2, fig. 1)}

The first step to improve urban climates is to study them (3, fig. 1) using climatic information (2, fig. 1). Meteorological stations (either traditional or automatic), complying with WMO rules, provide useful data to understand climate at the macroclimatic scale. However, these data are not appropriate for urban studies, due to the spatial scale of study and to the particular atmospheric processes that occur in the urban atmosphere. 
In the last decades, several developments have led to the improvement and normalisation of measurement methodologies and techniques of data acquisition in urban areas. Following Grimmond (2006), three aspects should be highlighted:

- Improved and more affordable instrumentation is now available to researchers due to the advances in technology, even in countries where only reduced sums of money are channelled into climatologic research. It is now possible to purchase reliable and accurate temperature and humidity sensors with data loggers, whereas some years ago only very expensive meteorological stations were available. A set of data loggers installed in key points in towns has replaced most of the mobile surveys, which were very time-consuming and had very limited temporal significance.

- Progress in urban atmospheric processes has led to a greater awareness of the importance of selecting correctly the location site for meteorological instrumentation in towns, either data loggers or meteorological stations. Fortunately, the "Initial guidance to obtain representative meteorological observation at urban sites" is now available (Oke, 2004). It is clear that location rules are different for studies carried out at different scales. In Lisbon, where both mesoclimatic and microclimatic temperature surveys were carried out during the CLIMLIS Project ${ }^{2}$, sites were chosen according to Oke's advice. In a first project, well distributed sites within the city, all with high sky view factors ${ }^{3}$ (SVF), were used to obtain information on temperature spatial variation in town ("settlement" scale), according to local climate factors and weather type (Alcoforado and Andrade, 2006). On a second project, which studied differences included in a single city district ("group of buildings" scale), data loggers were located in sites with different canyon geometry, street orientation and land cover, so that the causes of microclimatic differences could be inferred (Andrade and Alcoforado, in press).

- In order to prepare the way for future generations of researchers, a database of current studies, including metadata pertaining to measuring sites should be available. Researchers often have access only to long lists of figures with no information being provided regarding site exact location (latitude and longitude in degrees and minutes is insufficient), characteristics and site changes of meteorological stations; these are serious obstacles to the production of accurate work.

2 Prescription of Climatic Principles in Urban Planning. Application to Lisbon (Portugal) http://www.ceg.ul.pt/climlis/recent_dev.htm

3 The sky view factor is the "ratio of the amount of the sky 'seen' from a given point on a surface to that potentially available" (Oke, 1987: 404). 


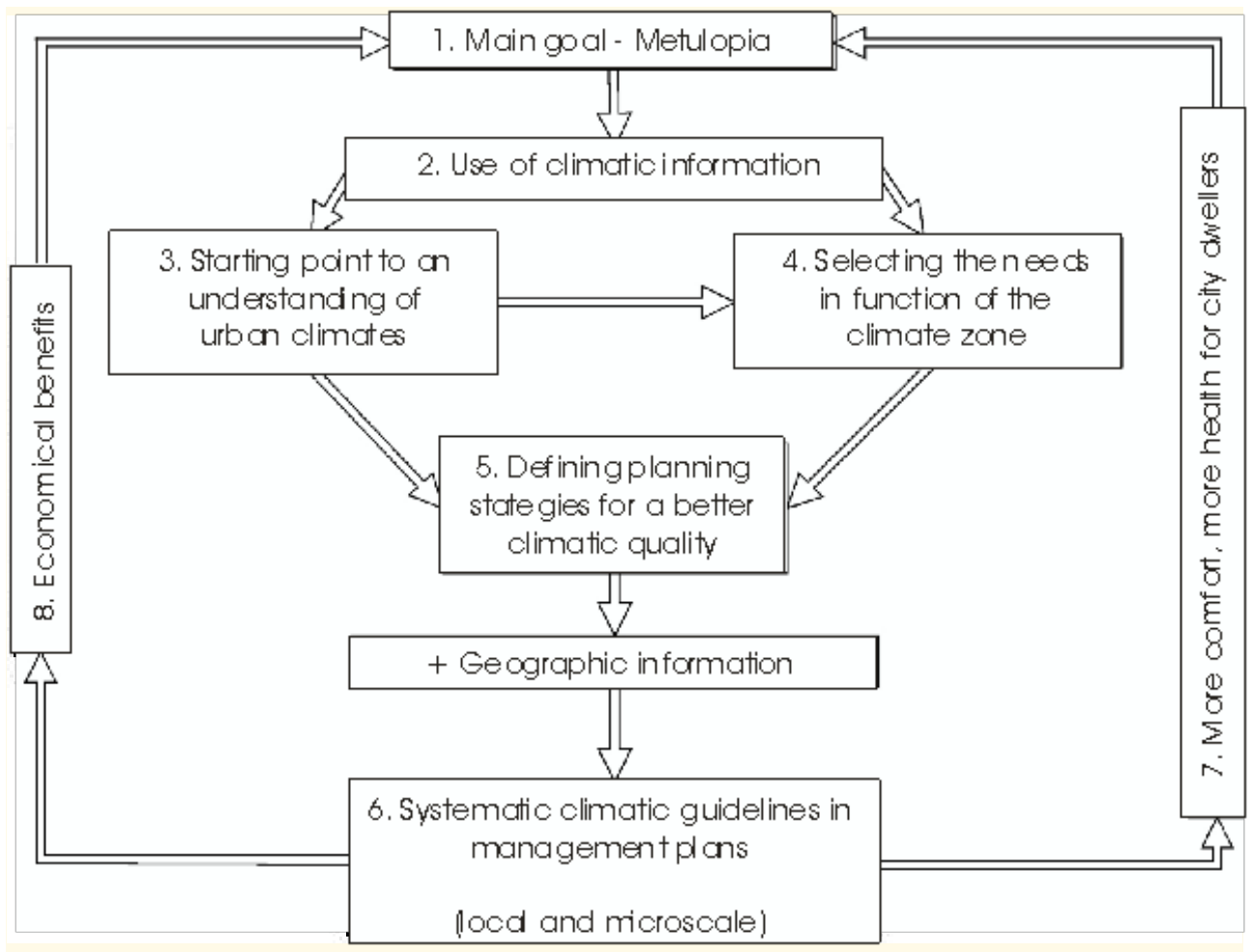

Fig. 1 - Flowchart showing the different stages of research towards a sustainable urban development.

Fig. 1 - Fluxograma ilustrando os diferentes estádios da investigação climática como contribuição para o desenvolvimento urbano sustentável.

\section{Starting point to an understanding of urban climates (3, fig. 1)}

For several decades now, climate data has provided the basis for scientists to get to know the characteristics of urban climates at different spatial and temporal scales. Since Kratzer's first manual in 1937, a number of review works on current knowledge of urban climate have been published: books by Landsberg (1981), Fezer (1995) and Oke (1987), papers by Oke (1988), Lowry (1998) and Arnfield (2003), among many others. Nowadays, statistical, scale and numerical modelling play a very important role. Nevertheless, climatic information will continue to be necessary, either to construct some of the models and/or to validate them. Furthermore, the aim of research should be to establish "general relations" and understanding the processes that cause urban climate rather than to continue mere studies of single cities (Oke, 2006).

Temperature, wind and air pollution, which are strongly dependent on cities morphology and anthropogenic activities, seem to be the main characteristics of urban climate. Anthropogenic activities can, to some extent, be "controlled" through meti- 
culous and informed planning. With regard to air temperature, the frequently used term urban heat island (UHI) refers to areas within the city, where the canopy and the boundary air layer temperature or the surface temperatures are higher than those of rural surroundings. The classical scheme by Oke (1987) shows air temperature rising from the suburbs towards the city centre. The temperature increase is not regular, but depends heavily on urban structure. The difference between urban and rural temperature is called UHI intensity (see Oke, 2006: 9). The UHI is more frequent and more intense during night time in most cities and during the dry season in tropical urban areas (Jauregui, 1997). The gradient wind is usually slowed down in the urban areas, although urban geometry may cause unwanted acceleration due to channelling along some streets or the venturi effect. Conversely, country and sea breezes may be intensified due to UHI. Cities are major sources of pollutants, which can be removed depending on the dispersion capability of the atmosphere (Batchvarova and Gryning, 2006) and also on wind speed and direction. UHI may intensify photosmog, but it also raises the mixing height, so its final effect on air pollution is not easy to predict (Rosenfeld et al., 1995). In cities, where topography and urban structure contribute to slowing down the wind, pollution problems can be very serious.

\section{Selection of the needs for different climate zones (4, fig. 1)}

Through the use of climatic information and the results of urban climate studies ( 2 and 3 , fig. 1 ) one is able to identify the climatic needs of cities within the studied area. The main requirements to mitigate negative impacts of urban climate will be briefly described according to the climate zone (Givoni, 1998; Brazdel and Martin, 1997; Alcoforado and Matzarakis, in print).

In hot areas, either humid or arid, UHI is a negative feature of the urban climate and must be mitigated. In hot humid climates it is necessary to reduce solar radiation and UHI. Furthermore, ventilation should be maximized and flood risks minimized. In hot arid climates measures should be taken to reduce solar gain and UHI, to increase evaporation in order promote cooling (green areas are effective if water is available for irrigation) and to minimize wind exposure.

In cold climates UHI is a positive feature, as it contributes to saving heating energy and it increases people's comfort on the streets; consequently, it must be favoured unless other negative consequences emerge (stagnant air between buildings may lead to enhanced air pollution); it is also necessary to maximize solar gain and minimize both wind exposure and snow accumulation (Zrudlo, 1988).

In areas with contrasting thermal seasons is UHI a positive or a negative feature? The UHI can be positive in winter, but threatens human comfort and health in summer. From the economic point of view, energy saving in winter is less important than the extra expenses of cooling cities in summer (in countries that can afford it, of course). Higher temperatures have additional negative consequences (oxidant pollution, bacteria multiplication, etc.). Consequently, in some cities such as Los Angeles and Athens, advice is given to planners to mitigate urban heat island (see also 4.1.). However, case-to-case evaluation must 
be carried out and solutions found accordingly, particularly in areas with climates with contrasting seasons.

\section{Defining planning strategies}

\subsection{General strategies (5, fig. 1)}

The next step is to use climatic knowledge when designing and planning at different spatial scales by choosing planning strategies for a better climatic quality (see also Alcoforado and Matzarakis, in print).

Mitigation of the UHI, for example, may be achieved through the modification of surface properties (Emmanuel, 2005) or street geometry (increasing the sky-view factor) whenever possible, reducing building density, integrating water bodies or green areas (Akbari et al., 2001; Ca et al., 1998). Yu and Hien (2006) consider that even in a humid hot climate like Singapore, the energy balance of the city may be modified by green areas (urban parks, rooftop gardens), as more absorbed energy "can be dissipated in form of latent heat rather than sensible heat". In a city with a Mediterranean climate like Lisbon, temperatures inside an 8.5 ha urban park (Gulbenkian Park) are on average (for a 60 days summer period) $1^{\circ}$ to $3^{\circ} \mathrm{C}$ lower than the nearby streets (Andrade and Vieira, 2005). Most frequently, the influence of the cooler air is not felt outside the park vicinity unless the topographical asset helps cold air drainage from the park into the nearby city-districts (Andrade, 2003). Further research is needed to conclude if several small neighbourhood green areas are more efficient in cooling the urban air than a big urban park.

The wind can be controlled in two distinct ways. In some city districts or along streets where the ratio between the height of the buildings and the width of the street $(\mathrm{H} / \mathrm{W}$ factor) is large, protection from strong winds must be created. But in most cases gradient winds are slowed down due to urban roughness: measures must then be taken to create open paths throughout the city to help ventilation. Country or sea breezes are sometimes very positive factors that enhance climate quality in town (Barlag and Kuttler, 1990/91), but sea breezes can also increase pollution in certain cases (Oke, 1987; Simpson, 1994). If new city districts are projected for a certain area, it is possible, through numerical or scale models, to identify beforehand the sites where the wind speed will be too strong, and the original plan can then be modified (Lopes, 2003; Baumüller et al., 2005).

Another problem is how to promote air quality in towns. This is not only a climatic problem and it depends a great deal on emissions, which are regulated by law and have numerous sources such as domestic heating (or cooling), industrial activities and vehicle emissions. Air quality can be improved by decreasing emissions and creating ventilation paths.

4.2. Strategies adapted to case-studies (6, fig. 1)

At this stage, it is possible to select planning strategies adapted to a particular city (6, fig. 1), using the result of the research carried out in 3 (fig. 1), based 
on climatological data and on different modelling strategies and taking into account the particular needs of the climatic zone where the city is located (4, fig. 1).

In 1984, Oke wrote that only a small amount of urban climate knowledge had permeated to urban planners due to "inherent complexity of the subject, its interdisciplinary nature and lack of meaningful dialogue between planners and the climatological research community" (p.1). Since then only a few papers have shown that some steps have been taken towards the introduction of climatic principles in settlement planning. For example, in 1988 Bitan suggested a methodology that would enable planners, as well as architects, to integrate climatic information at all levels of planning, from the settlement planning to the design of buildings (Bitan, 1988: 1). The methodology is synthesised in a flowchart divided into five main stages three of which involve climatological data acquisition and processing (p. 4). In the same year Zrudlo presented a "climatic approach to town planning in the Arctic", where a case study was carried out on a wooden house Inuit settlement constructed by the Canadian government near the Hudson Bay. He identified sun, wind and snow as the major stressors in this area. The final plan takes into consideration not only individual plans drawn separately for each climate element, but also the conflicts arising among them. At the end a "synthesized plan (was produced) which offers maximum solar advantage, wind protection and minimum snow-drifting, contributing (...) to the efficient functioning of the town and to the general well-being, both physically and psychologically, of its inhabitants" (Zrudlo, 1988: 62-63).

Several climatic analysis on urban planning have been performed in Germany since 1970 . Firstly in the very densely populated $R u h r$ area, then in projects on the urban climate of Bavaria (several cities in southern Germany in 1980s), followed by many others including projects STUTTGART21 (Baumüller, 2005) and BERLIOZ on Berlin (all references and explanations are found in Matzarakis, 2005). In most of those works "synthetic climate-function maps" and maps containing guidelines for planning are presented. The "Climate booklet for urban development" (Baumüller et al., 2005) provides a very useful tool for planning related urban climate studies.

In the Graz area in Austria, the main climatic problems are inversion conditions, low ventilation, fog and high pollution levels: Lazar and Podesser (1999) presented detailed maps of areas still free from buildings and sites of "banned" or "restricted" construction.

Within the framework of the KABA Project (Klima Analyse der Region Basel, Scherer et al., 1999), two types of maps were produced: the climate analysis maps and climate recommendation maps for regional and urban planning. An automated classification of planning objectives for the consideration of climate and air quality in Basel region was made by the University of Basel work team (Fehrenbach et al., 2001). The main objectives were the "protection of sensitive areas, the improvement of problematic situations, risk assessment and reduction and recommendations for appropriate forms of land-use". This classification has the advantages of being operator-independent and it can be applied elsewhere. 
Other references and case-studies can be found in the IAUC Newsletter (http://www.indiana.edu/ iauc/), in sites from ICLEI (Local Governments for sustainability, http://www.iclei.org/index.php?id=643), the heat island group home page (http://eetd.lbl.gov/heatisland/), and several others.

Within the CLIMLIS Project (see footnote 2), climate analysis was carried out for urban planning in Lisbon (Portugal). Lisbon is located near the western coast of Portugal, at $38^{\circ} 43^{\prime}$ latitude $\mathrm{N}$ and $9^{\circ} 9^{\prime}$ longitude W. The city lies $30 \mathrm{~km}$ to the east of the Atlantic shore and right on the bank of the Tagus estuary, that is $15 \mathrm{~km}$ wide eastwards from Lisbon. The city covers $84 \mathrm{~km}^{2}$ and has circa 600 000 inhabitants. In the urbanized area, altitude is inferior to $160 \mathrm{~m}$, although the topography is highly differentiated: four main valleys run from the north to the south in the most southern part of Lisbon. To the west, the Monsanto Hill rises to just over $200 \mathrm{~m}$ (fig. 2a). The traditional centre lie near the river and the new centrality area is expanding northwards. Its climate is 'Mediterranean' meaning that the dry season is the warmest and there are contrasting thermal seasons.

The city's main climatic problems detected on the basis of previous research were: urban heat island (UHI), wind, air pollution and urban floods. As the latter was being studied elsewhere (Oliveira and Ramos, 2002), we have focused on the first three items. Lisbon's UHI has an average intensity of $3^{\circ} \mathrm{C}$ and the nocturnal thermal pattern is frequently like the one in figure $2 b$ (Andrade, 2003) : $^{4}$ the highest air temperatures occur mostly in the more densely constructed areas, both near the Tagus river bank and along the main circulation axis where construction has been in progress. Prevailing N and NW wind circulation is hindered by the densely built-up southern and central neighbourhoods. In the case of a strong north wind, the UHI is restricted to the southernmost city districts where not only topography but also built-up density creates sheltered conditions. By way of a numerical model, summer wind speed reduction until the 1980s (an important decade in Lisbon's urban expansion) was simulated (Lopes, 2002 and 2003). Wind speed decrease due to surface roughness was particularly important in the densely built-up southern city-districts and over the Monsanto hill (fig. 2a). Nowadays, construction keeps on progressing north of the boundary between the well ventilated northern districts and the southern areas (with very restricted ventilation, fig. 2a). There are still open spaces in the northern city-districts, where ventilation paths for prevailing $\mathrm{N}$ winds must unquestionably be kept free (Lopes, 2003). The Tagus breeze does not always penetrate very far inland, but it is a very important source of cool air for the riverside neighbourhoods. (Vasconcelos et al., 2004). Lisbon has not yet become a very polluted city, mainly on account of frequent winds and because the vertical temperature profiles that promote pollution concentration are not very frequent. However, legal thresholds are sometimes exceeded, as was the case on January 1993, when frequent anticyclonic calm conditions occurred (Andrade, 1996). It is also clear that for the good of air quality, air circulation should not be hindered.

4 Coloured figures are included in the electronic version (www.ceg.ul.pt/finisterra/index.htm) 
In order to draw a climate guideline map it was first necessary to prepare a cartographical basis with the physical characteristics of the city. Hence homogeneous climate response units ${ }^{4}$ (CR units from the point of view of urban morphology, topography and position in town) were represented in a 1:25 000 map. The work was carried out using a geographical information system. Several layers were necessary such as land use (based on a Landsat 7 image), height of buildings, Digital Terrain Model, etc.

Recommendations for planning purposes are given for each homogeneous unit or group of units according to the work scale; it is known that planners need very clear guidelines concerning areas whose limits are very precisely drawn in a detailed map. In fact, the maps of figure 3 show only the different groups of CR units defined on a "settlement" scale (1 to 6, fig. 3 ). The descriptive captions consists of tables where recommended measures to mitigate UHI, enhance ventilation and decrease air pollution in each unit group are listed. They are presented in detail in Alcoforado et al. (2005). Measures differ according to position and type of homogenous unit. For instance, setting up green areas in the northern part of the city (unit 1) may be advised to moderate UHI, while in the city core (unit 6), one can only recommend planting some deciduous trees in the few areas that are still left. In the northern part of the city large ventilation paths (unit 2) can still be preserved, while in the city centre, the only possible measure is to not obstruct the valley beds even further.

Similar methodology, this time also using scale modelling (Andrade, 2003; Lopes, 2003), was applied on a scale of "group of buildings" in a city district in the northern area of Lisbon where construction has been in constant progress (Andrade and Alcoforado, in press). Conflicts between planning measures at the two different scales had to be dealt with. For example, at the settlement scale, large ventilation paths were recommended; however, in the city-district under study, guidelines were given in order to provide shelter in outdoor areas used for leisure activities.

\section{CONSEQUENCES OF USING CLIMATE GUIDELINES IN URBAN PLANNING}

\section{Benefits in terms of comfort and health for city dwellers (7, fig. 1)}

Although there are other positive consequences for the city dweller including climatic recommendations in urban planning, only their effect on thermal

4 The methodology to limit these units was inspired by the different research works referred to at the beginning of this paragraph. The homogeneous climate response units may also be called morpho-topographical units, climatopes (VDI, 1998, Scherer et al., 1999) or be the synthesis of the areal type and ventilation classes, used in the work of Feherenbach et al., 2001. The methodologies and the denomination of these units are discussed in Alcoforado et. al. (2005). 
comfort will be presented here. Human comfort changes a great deal spatially and temporally and it is a highly subjective parameter. However, several attempts have been made to "quantify" the way in which the human body reacts while seeking its comfort zone. One of the most commonly used bioclimate comfort indices is the Physiological Equivalent Temperature (PET), first defined by

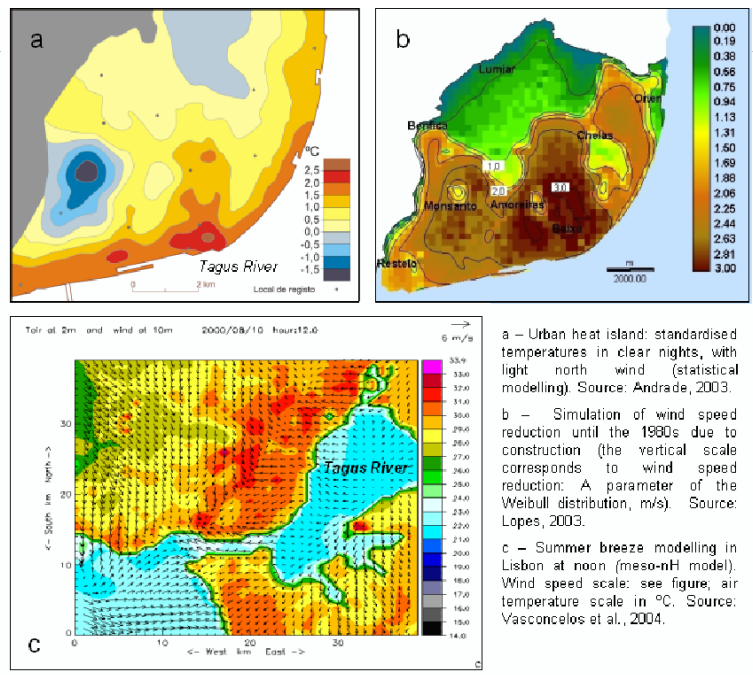

Fig. 2 - Examples of previous work on Lisbon's urban climate.

A) Wind speed reduction until the 1980s (Lopes, 2003); B) Frequent nocturnal thermal pattern (standardized temperatures, ${ }^{\circ} \mathrm{C}$, Andrade, 2003).

Fig. 2 - Exemplos de investigação preexistente sobre o clima urbano de Lisboa. A) Redução da velocidade do vento até 1980 (Lopes, 2003); B) Padrão térmico nocturno frequente (temperaturas normalizadas, ${ }^{\circ} \mathrm{C}$, Andrade 2003)

Mayer and Höppe (1987) and Höppe (1993). This index is based on the energy balance of the human body and, according to Matzarakis, Mayer and Iziomon (1999), it allows for the evaluation of thermal conditions in a physiologically significant manner. It is used systematically in planning practices in Germany (Matzarakis et al., 2000; VDI, 1988) and is applied in the evaluation of different thermal environments, such as the UHI within cities. At the "settlement" scale, Andrade (2003) has shown that the highest values of PET in Lisbon occur in the UHI core and that PET differences between the suburbs and the city centre are even higher than UHI intensity. This means that changes in thermal environment, due to different planning measures, can be quantified by the use of PET and that UHI mitigation will lead to a decrease of thermal stress and, as a consequence, to a decrease in urban morbidity and mortality.

In rural areas, and more so in cities, additional health problems are expected as a result of global warming (WHO, 2005; Koppe et al., 2004). Conversely, "in cities stagnant weather conditions can trap both warm air and pollutants leading to smog episodes with significant health impacts"; moreover, recent 


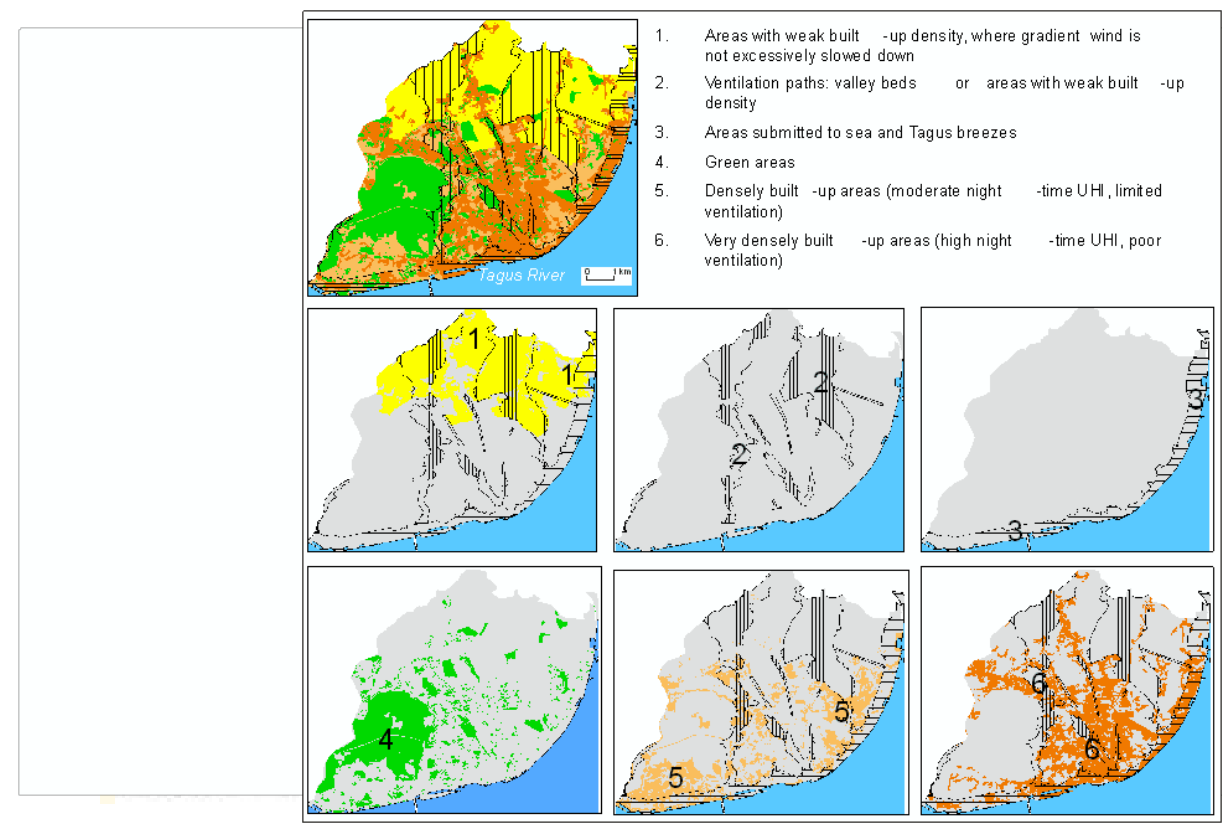

Fig.3 - Groups of homogeneous Climate Response Units for which climate guidelines were prepared (Lisbon, "settlement scale").

Fig.3 - Grupos de unidades de resposta climática homogénea de Lisboa para as quais foram feitas recomendações climáticas (na escala mesoclimática).

analysis shows "that human induced climate change significantly increased the likelihood of the European summer heat wave of 2003" (WHO, 2005).

\section{Economical benefits for city dwellers (8, fig. 1)}

According to Oke (2006), there are few examples that illustrate the positive or negative impact of design inspired or informed by urban climate input. This is particularly true insofar as economic benefits are concerned. There is not yet an accepted common methodology to compute the costs and benefits of urban climate, mainly of the UHI. However, some figures were presented for cities with thermal contrasting seasons: Athens (Dimoudi and Nikolopoulou, 2003; Hassid et al., 2000), Los Angeles (Akbari et al., 2001) and Tokyo (Genchi et al., 2004). A more detailed account and some other references are given in Alcoforado and Matzarakis (in print). Some papers present figures to prove that the saving of energy in winter is lower than the surplus expenses for air conditioning in the summer. On the other hand, generalised air conditioning systems will represent an unwanted added heat load to the urban atmosphere. The problem can be more complicated to solve in areas with hot and humid seasons. Yu and Hien (2006: 119) computed $10 \%$ reduction of cooling load in buildings near a park in Singapore. However, the authors indicate that the energy used for dehumidifying was not considered in the simulation. Much research is still needed in this area. 


\section{CONCLUSION (back to 1, fig. 1)}

It is clear that some of the difficulties, pointed out by Oke (1984) and Eliasson (2000), concerning the application of urban climatology to planning of sustainable settlements, as has been briefly analysed here, have not yet been solved. Some climate studies are not directly usable by planners and some planners are not yet acquainted with the results of climate studies or even with the possibility of using climatic information. There is still, in some cases, a "communication" problem between climate scientists and planners, and even when they speak the same language "translation" problems often arise. Moreover, the ideal sustainable city does not look the same to climatologists and planners; e.g., the example of the compact city, supported by some planners for economic reasons (for instance, per capita energy use is much lower in high density cities). Climate scientists consider that the compact city leads to climatic problems, as inadequate ventilation in compact cities will lead to temperatures that are too high and to excessively high pollution levels, if no measures are taken to counteract them (Mills, 2006). As was pointed out in the case of outdoor comfort, and more so in the case of economic consequences, there are not enough measurable impacts of using climate knowledge in different planning levels.

However, several positive aspects must also be highlighted. From the examples presented and cited in this paper as well as from several others quoted by Eliasson (2000), Mills (2006) and Alcoforado and Matzarakis (in print), just to mention a few, it is clear that as climate is part of the physical environment it has its place in the urban planning process. Furthermore, in several ongoing applied studies the climate information used is not restricted to simple average values of the nearest meteorological station as it traditionally was. Urban climate knowledge is slowly being made known to the public and local authorities with the power to implement necessary measures. Some publications explain the advantages of using urban climate knowledge in planning procedures and give the planners tools to use climate information in their work or to fall back on climate researchers. The "booklet" edited by Baumüller et al. (2005) on the Internet in German and English now being translated into other languages (Matzarakis, 2005) is quite a good example. Following this initiative, climatologists and planners together should prepare a standard protocol so that future urban management plans systematically include climate guidelines. Maybe this way we will all get closer to meteorologically utopian cities.

\section{AKNOWLEDGEMENTS}

I would like to thank the members of the ET9 (OPAG3) of the WMO, those of the CLIMLIS team, Andreas Matzarakis and Eberhard Parlow, for the fruitful discussions about urban climate and planning issues, as well as Henrique Andrade for his very useful comments on a former version of this text. 
Furthermore, the comments of the reviewers of Finisterra must be thanked. The present text was adapted from a paper presented at the Beijing Conference on Climate Resources, in November 2005, where the author was sponsored by the WMO.

\section{REFERENCES}

Akbari H, Pomerantz M, Taha H (2001) Cool surfaces and shade trees to reduce energy use and improve air quality in urban areas. Solar Energy, 70: 295-310.

Alcoforado M J, Andrade H (2006) Nocturnal urban heat island in Lisbon (Portugal): Main features and modelling attempts. Theoretical and Applied Climatology, 84(1-3): 151-160. http://springerlink.com/content/w848535781465135/

Alcoforado M J, Andrade H, Lopes A, Vasconcelos J, Vieira R (2005) Orientações climáticas para $o$ ordenamento em Lisboa. Área de Investigação de Geo-Ecologia, Relatório n. ${ }^{\circ} 4$, Centro de Estudos Geográficos, Lisboa 81 p.

Alcoforado M J, Matzarakis A Urban climate and planning in different climate zones. Chapter of the new edition of WMO/TN 145, Geneva (in press).

Andrade H (2003) Human bioclimate and air temperature in Lisbon (in Portuguese). PhD Thesis, University of Lisbon.

Andrade H (1996) Air quality in Lisbon. Average and extreme values (in Portuguese). Finisterra-Revista Portuguesa de Geografia, XXXI(61): 43-66.

Andrade H, Alcoforado M J Microclimatic variation of thermal comfort in a district of Lisbon (Telheiras) at night. Theoretical and Applied Climatology (no prelo).

Andrade H, Vieira R (2005) The Climate of the Gulbenkian Park (Lisbon). Área de Investigação de Geo-Ecologia, Relatório n. ${ }^{\circ}$ 4, Centro de Estudos Geográficos, Lisboa (in Portuguese with an English summary).

Arnfield J (2003) Two decades of urban climate research: a review of turbulence, exchanges of energy and water, and the urban heat island. International Journal of Climatology, 23: 1-26.

Barlag A B, Kuttler W (1990/91) The significance of country breezes for urban planning. Energy and Buildings, 15/16: 291-297.

Batchvarova E, Gryning S (2006) Progress in urban dispersion studies. Theoretical and Applied Climatology, 84(1-3): 57-68.

Baumüller J (2005) "Stuttgart 21". Amt für Umweltschutz, Stuttgart [Acedido em 15 de Outubro de 2005]. http://www.stadtklima.de/stuttgart/websk21/Heft13/kap3.HTM

Baumüller J, Hoffman U, Reuter U (2005) Climate booklet for urban development. References for zoning and planning. Baden-Württemberg Innenministerium [Acedido em 16 de Outubro de 2005] http://www.staedtebauliche-klimafibel.de/

Bitan A (1992) The high climatic quality of the future. Atmospheric Environment, 26B(3): 313-329.

Bitan A (1988) The methodology of applied climatology in planning and building. Energy and Buildings, 11: 1-10.

Brazel A, Martin J (1997) Town planning, architecture and building, In Thompson and Perry (eds), Applied Climatology. Principles and Practice. Routledge, London: 175-186.

Ca V T, Asaeda T, Abu E M (1998) Reductions in air conditioning energy caused by a nearby park. Energy and Buildings, 29: 83-92. 
Dimoudi K, Nikolopoulou M (2003) Vegetation in the urban environment: microclimatic analysis and benefits. Energy and Buildings, 35: 69-76.

Eliasson I (2000) The use of climate knowledge in urban planning. Landscape and Urban Planning, 48: 31-44.

Emmanuel R (2005) Thermal comfort implications of urbanization in a warm-humid city: the Colombo Metropolitan Region (CMR), Sri Lanka. Building and Environment, 40: 1591-1601.

Fehrenbach U, Scherer D, Parlow E (2001) Automated classification of planning objectives for the consideration of climate and air quality in urban and regional planning for the example of the region Basel/Swizerland. Atmospheric Environment, 35: 5605-5615.

Fezer F (1995) Das Klima der Städte. Klett-Perthes Verlag, Gotha.

Genchi Y, Azuma T, Ohashi Y, Kikegawa Y, Inaba A (2004) Energy analysis of countermeasures for urban heat island effect. Proceedings of the 6th International Conference on EcoBalance, S2-6-1, Tsukuba, Japan: 4p.

Givoni B (1998) Climate considerations in building and urban design. John Wiley and Son, New York.

Grimmond C S B (2006) Progress in measuring and observing the urban atmosphere. Theoretical and Applied Climatology, 84(1-3): 3-22.

Hassid S, Santamouris M, Papanikolaou N, Linardi A, Klitsikas N, Georgakis C, Assimakopoulos D N (2000) The effects of the Athens heat island on air conditioning load. Energy and Buildings, 32: 131-141.

Höppe P R (1993) Heat balance modelling. Experientia, 18: 1-15.

Jauregui E (1997) Climates of tropical and subtropical cities. In Yoshino M, Domrös M, Douguédroit A, Paszynski J, Nkemdirim L (eds) Climates and Societies. Dordecht, The Geojournal Library, Kluwer: 361-373.

Koppe C, Jendritzky G, Kovats S, Menne B, Baumüller J, Bitan A, Díaz Jiménez J, Ebi K L, Havenith G, López Santiago C, Michelozzi P, Nicol F, Matzarakis A, McGregor G, Nogueira P J, Sheridan S, Wolf T (2004) Heat-waves: risks and responses. Regional Office for Europe. Health and Global Environmental Change, Series No. 2, Copenhagen http://www.euro.who.int/document/E82629.pdf

Kratzer A (1937) Das Stadtklima. Vieweg, Braunschweig.

Landsberg H (1981) The urban climate. International Geophysics series, 28, Academic Press, New York.

Landsberg H (1973) The meteorologically utopian city. Bulletin American Meteorological Society, 54(2): 86-89.

Lazar R, Podesser A (1999) An urban climate analysis of Graz and its significance for urban planning in the tributary valleys east of Graz Austria). Atmospheric Environment, 33: 4195-4209.

Lopes A (2003) Changes in Lisbon's urban climate as a consequence of urban growth. Wind, surface UHI and energy budget. (in Portuguese). PhD Thesis, University of Lisbon.

Lopes A (2002) The influence of the Growth of Lisbon on summer wind fields and its environmental implications. Proceedings of the Tyndall/CIB International Conference on Climate Change and the Built Environment, Manchester, UMIST, 9 p.

Lowry W P (1998) Urban effects on precipitation amount. Progress in Physical Geography, 22: 477-520.

Matzarakis A (2005) Urban climate research in Germany. IAUC Newsletter, 11: 4-6 http://www.indiana.edu/ iauc/ 
Matzarakis A, Mayer H, Iziomon M G (1999) Applications of a universal thermal index: physiological equivalent temperature. International Journal of Biometeorology, 43: 76-84.

Matzarakis A, Rutz F, Mayer H (2000) Estimation and calculation of the mean radiant temperature within urban structures. WCASP-50, WMO/TD No. 1026: 273-278.

Mayer H, Höppe P R (1987) Thermal comfort of man in different urban environments. Theoretical and Applied Climatology, 38: 43-49.

Mills G (2006) Progress towards sustainable settlements: a role for urban climatology. Theoretical and Applied Climatology, 84(1-3) 69-76.

Mills G (2003) The meteorologically utopian city revisited. Proceedings of the $5^{\text {th }}$ International Conference on urban Climate, Lodz, Poland, vol. 2: 227-230.

Oke T R (2006) Towards better scientific communication in urban climate. Theoretical and Applied Climatology, 84(1-3): 179-189.

Oke T R (2004) Initial guidance to obtain representative meteorological observations at urban sites. IOM Report, n. 81, WMO/TD No. 1250, Geneva, World Meteorological Organization, http://www.wmo.ch/web/www/IMOP/publications/IOM-81/IOM-81-UrbanMetObs.pdf

Oke T R (1988) The urban energy balance. Progress in Physical Geography, 2(4): 471-508.

Oke T R (1987) Boundary Layer Climates. Methuen, London, ( $2^{\text {nd }}$ ed.).

Oke T R (1984) Towards a prescription for the greater use of climatic principles in settlement planning. Energy and Buildings, 7: 1-10.

Oliveira P E, Ramos C (2002) Urban floods in Lisbon during the 20th century and its causes. (in Portuguese, with an English summary). Finisterra - Revista Portuguesa de Geografia, XXXVII(74): 33-54.

Rosenfeld A H, Akbari H, Bretz S, Fishman B L, Kurn D M, Sailor D, Taha H (1995) Mitigation of urban heat islands: materials, utility programs, updates. Energy and Buildings, 22: 255-265.

Scherer D, Fehrenbach U, Feigenwinter C, Parlow E, Vogt R (1999) Improved concepts and methods in analysis and evaluation of the urban climate for optimising urban planning processes. Atmospheric Environment, 33: 4185-4193.

Simpson J E (1994) Sea breeze and local wind. Cambridge University Press.

Vasconcelos J, Lopes A, Neto J, Salgado R (2004) Modelling estuarine breezes of Lisbon, Portugal. Preliminary results. Proceedings of the IV Conference of the Spanish Association of Climatology, Santander: 165-171.

VDI (ed.) (1988) Stadtklima und Luftreinhaltung. Springer-Verlag, Berlin.

WHO (2005) Climate and health. [Acedido em 07 de Fevereiro de 2006] http://www.who.int/globalchange/ news/fsclimandhealth/en/

Yu C, Hien W N (2006) Thermal benefits of city parks. Energy and Buildings, 38: 105-120.

Zrudlo L R (1988) A climatic approach to town planning in the Artic. Energy and Buildings, 11: 41-63. 